\title{
Impact of interaction term between education and loan size on women's decision making
}

\author{
Kausar Yasmeen (Corresponding author) \\ Candidate of $\mathrm{PhD}$, School of Economics, Banking and Finance \\ UUM College of Business (COB), Universiti Utara Malaysia, 06010 Sintok, Kedah, Malaysia
}

E-mail: eco.yasmeen@gmail.com

Prof. Dr Mohd Zaini Abd Karim

Othman Yeop Abdullah Graduate School of Business

Universiti Utara Malaysia, 06010 Sintok, Kedah, Malaysia

Doi:10.5296/ jebi.v1i1.6658 URL: http://dx.doi.org/10.5296/ jebi.v1i1.6658

\begin{abstract}
The purpose of this paper is to evaluate the impact of the microfinance involvement of women's household decision making. The cross sectional data for this study is collected by using questionnaires. Using random sampling, 744 households are selected from female clients of Khushhali Bank and National Rural Support Program in Bahawalpur Division, Pakistan. We used the multinomial Logit and multinomial Probit model. The results show the woman's borrowers are more empower than women no borrowers. The coefficient of the loan size increases woman's household making empowerment. This paper is intended to be a valuable contribution in term of socio- economic and political arena.
\end{abstract}

Keywords: Microfinance, women's household decision making, probabilities, Pakistan 


\section{Introduction}

Kofi Annan UN Secretary- general (2006) discussed that there is no effective tool to achieve development except women's empowerment. For its chief proponents, empowerment is a humanistic device to increasingly being viewed as one of the key con- constituent elements of the poverty reduction strategy. It is not only seen as a development objective in itself but as a means of promoting growth, re- during poverty and promoting better governance (World Bank, 2001).Working females are not only contributing to the national income, but also plays a vital role to maintain a sustainable livelihood of the communities and families. Females in the western countries play a larger role in improving the income of their countries than the females living in poor and backward areas like Pakistan. In developing countries like Pakistan, especially in the rural areas, unfortunately females are still facing many legal barriers, socio- cultural attitude, lack of education and personal difficulties. The problem of poverty cannot be resolved without money as money generates money or service generates money. The problem is that most females do not have access to finance to start their business to meet their needs and to overcome poverty. In the past, the resources of financing were limited, but now globally, women are being supported. Several programs served the women by providing them with financing. Microfinance is one of the financial services that targets small borrowers especially women. According to the Official Report on Strategic Framework for Sustainable Microfinance in Pakistan (2011), there is interest on the Pakistani government and state bank of Pakistan to promote women's empowerment in Pakistan. This report highlights the importance of microfinance institutions in Pakistan. Since 2000, Pakistan has supported microfinance institutions to empower women. In Pakistan, the microfinance sector is underdeveloped and is relatively young.

\section{Literature Review}

Females living in developed countries contribute to their national income more than women living in underdeveloped and developing countries. The household development of the country depends on both working male and female. In the developed countries, women have household decision power and freedom. To improve thehouseholdpower of public and household development of under developing countries like Pakistan, developed countries provide loans through different programs through IMF and World Bank. The Pakistani government to secure loans from IMF and World Bank and spend this money on different projects for the well-being of the nation. When government starts projects, it needs machinery and human capitals to implement the project gives hence provide employment to people. However, women living in rural areas of Pakistan are still facing problems of social barriers, freedom in decision making, etc. Relative to most countries globally, Pakistan has male dominant society, especially in the rural areas. There are restrictions on women where they neither moves outdoor nor are allowed to have social contacts with male society. Women faced many cultural and social barriers to enter into the formal labor market. However, they also face problems when they enter into the informal sector. Women in urban areas have relatively easy access to informal sources of credit like money lender, friends and relatives more than females living in rural areas but, they are charging high rate of interests (TLO, 1998 
Some studies (Hasherniet al. 1996, Parveen, 2007) have highlighted that accessibility to loan through the poor has a big positive impact on empowerment, quality of life and living standard. Rehman and Khan (2007), attempted to explore how microfinance helps poor people to improve their living standard. They concluded that provision of microfinance in the form of collateral free loans is an effective mechanism for reduction of poverty, improving health, education, legal rights, sanitation. Chaudary and Nosheen (2009) narrate that the micro credit has a significant impact on women empowerment. Nevertheless, on the basis of the previous studies, limited evidences exist on which type of empowerment is more significant for poor female. The above previous studies show the positive impact of microfinance empowerment. However, some studies also show that microfinance has no impact on women's empowerment. Chowdhury (2008) found that in Pakistan, poverty is not declining through micro-finance, as poor households simply remain poor because of the extra burden of interest rate and debt. Microfinance institutions charge high rate of interest, where this interest rate has an inverse relationship with empowerment. Asim (2008) found that the microfinance has no positive impact on female empowerment.

On the basis of the above discussion, we can conclude that there are mixed results, Hasherni et al. (1996), Parveen (2007) andBanuet al. (2000) found positive impact of microfinance on empowerment, while Asim (2008) found a negative impact of microfinance on women empowerment in Pakistan.

\subsection{Loans and women empowerment}

Microfinance and empowerment Microfinance is regarded as a means to empower developing countries by supporting entrepreneurship. Scholars such as Woodworth (2000) argue that microfinance is needed to lift developing countries out of poverty (Khandker, 2005). In contrast to conventional development aid, microfinance involves and often even focuses on the informal sector (Alter Chen,2005) and may be an alternative to macroeconomic solutions that are often used in development aid programs(Woodworth, 2000).

Negative consequences of the informal sector's importance are, that potential borrowers mostly are not aware of the products and services that are offered by microfinance institutions and commercial banks or that they are not able to access loans because of their illiteracy or knowledge in regional languages(ShabibulHasan, 2012). Additionally, credit evaluation procedures of institutionalized lenders are often stricter than those of informal lenders preventing borrowers from asking for loans at commercial banks of microfinance institutions (Arora\&Meenu, 2011).

With respect to the gender of the micro borrowers, an analysis conducted by Woodworth (2000) suggests that $65 \%$ of all microloans were provided to women in order to help them to start or maintain an enterprise with some institutions having even higher rates of loans for women (Chowdhury\&Chowdhury, 2011; Noponen, 2003). Often, microfinance focuses on the empowerment of women in order to enable them gain a greater degree of control over their destinies (Paxton, 1995). Studies suggest that microfinance is able to increase women's upward mobility and their influence on family decisions (Todd, 1996), both being a part of 
empowerment (Muhammad et al., 2012). Another rationale for focusing on female borrowers is the lower default rate compared with male borrowers (D'Espallier, Gue'rin, \&Mersland, 2011) though some studies could not replicate this argument (Godquin,2004). But does the provision of loans to women automatically guarantee the empowerment of female borrowers? Hunt and

Kasynathan (2001) suggest that in order to guarantee the empowerment of female borrowers, microfinance institutions should have an understanding of gender issues and women's rights and have implemented this understanding in their own organization. Aspects of empowerment should be monitored continuously after having provided a microloan and a clear mission on the importance of women having control over decision- making related to the use of their loan should be implemented.

Furthermore, training programs should support this mission. Ali and Hatta (2012) demonstrate that a "minimalist approach of microfinance" that mainly takes the repayment rate and the financial sustainability of the microfinance institution into account does not create a significant impact on empowerment. They demonstrate that women's empowerment must not be a consequence of microfinance but that it may be achieved if it is integrated in the vision, strategy, and operations of microfinance institutions (Haile, Bock, \&Folmer,2012). Swain and Wallentin (2009) conducted one of the few studies that used a quasi-experimental approach to test whether microfinance had an impact on the empowerment of women. Their results suggest that women who were members of a microfinance program experienced a significant increase in empowerment compared to a non-member group. In another study, using a multivariate approach and working with a sample and a control group, Chowdhury and Chowdhury (2011)concluded that the participation in a microloan program created significantly higher outcomes, including empowerment, for the participants.

From a methodological and theoretical standpoint, Kabeerargues that differences in studies with respect to empowerment of women through microfinance arise because different concepts or aspects of empowerment such as intra-household power relations (Kabeer, 2001) vs. an increase of the financial situation of a borrower are applied. Depending on the understanding of the concept of empowerment, different studies suggest different impacts of microfinance on women empowerment, for instance, health care (Rai\& Ravi, 2011).

In addition to the provision of a loan, external livelihood and personal factors may influence the success of microloans. External variables may be market characteristics, entrepreneurial

and market knowledge as well as numerical and financial literacy (Leach \&Sitaram, 2002). Khan and Noree (2012)identified age, education of the husband, father-inherited assets, marital status, number of sons alive, and the amount of microfinance as covariates that influence empowerment in addition to the direct impact of microfinance.

Obviously, other external factors such as infrastructural development, access to resources, skill building trainings, borrowers' education, mobility, labor availability, and other factors have an impact on women's empowerment (Otero,1999). Because of these external effects the study was conducted in a particular region in Pakistan to guarantee comparable conditions 
for borrowers with respect to external socio-political factors. According to Ngo and Wahhaj (2012) microfinance increases the empowerment of women, if it is invested profitably in a joint activity, and when a large share of the household budget is spent for household public goods.

Consequently, the study suggests the loan to be invested in a joint business run by husband and wife. Hence, it seems that a number of external variables, such as societal impacts, family relations, and knowledge, moderate the impact of microfinance on empowerment (Khan \&Noree, 2012).

\subsection{Measuring the impact of microfinance on empowerment}

Empowering people is an important-but not the exclusive- mission of microfinance (Kabeer, 2001). Controlling non-financial aspects of microfinance, however, is important to be able to manage potential positive effects, such as resulting from family-based micro enterprises (Maldonado \&Gonza'lez-Vega, 2008) or the risk of overindebtedness. Though many studies explore methods for measuring microfinanceimpacts (Weber, 2013), it is still unclear how effects of microfinance can be evaluated. Common impact measurement methods are outreach measurement (Cull, Demirguec_-Kunt, \&Morduch, 2007; Yaron, 1992a), which sometimes includes social outreach (BartualSanfeliu, Cervello' Royo, \&MoyaClemente, 2013), and social cost-benefit analysis (Bhatt \&Tang, 2001; Stewart, 1975). Neither method focuses on the measurement of empowerment, however. Many outreach studies focus on the number and the size of loans and the group of borrowers receiving the loans. The approach assumes that smaller loans, being provided to borrowers at the base of the pyramid, create a higher outreacthan bigger loans to small- and medium-sized enterprises. Size and type of borrower are the main indicators that are assessed in outreach measurement studies that are often used to compare different types of microfinance institutions such as those following a poverty alleviation approach vs. those following a financial systems approach (Hishigsuren, 2007; Mersland\&Strøm, 2010; Morduch, 1999; Yaron, 1992b). Social cost-benefit analyses concentrate on costs, such as administrative costs or capital costs, and both financial and social benefits of the microfinance business for the respective institutions and their clients (Stewart, 1975). Shadow prices are often used to measure the value of social costs and benefits. The method is often applied to evaluate the efficiency of microfinance compared with other means of poverty alleviation (Bhatt \& Tang, 2001) such as publicly financed development aid (van de Walle, 1997).

\subsection{Methodological issues of measuring the impact of microfinance:}

Empowerment When it comes to measuring the impact of microfinance on empowerment, a number of methodological issues have to be dealt with. The first issue is to operationalize empowerment. As mentioned above, empowerment is not a uni-dimensional variable but a multidimensional construct. Therefore, the components of empowerment have to be selected, and to be merged into a measurable construct that can be tested regarding its validity. The second issue is the cause-effect relation between microfinance and empowerment. The use of case studies without control groups is not able to analyze cause-effect relations in contrast to control-group studies like the one by Chowdhury and Chowdhury (2011). Therefore, the 
presented study useda control-group setting that tests cause and effect relations between microloans and a multidimensional construct of empowerment. Thirdly, many studies use outreach measurement and focus on the characteristics of the borrowers, their social status or

gender, and on loan size (Hermes \& Lensink, 2011; ShabibulHasan, 2012). Though these indicators are important, however, they do not indicate the social impact of microfinance directly. Accounting for the percentage of women borrowers may be an indication for striving to improve female borrowers' empowerment, but it does not explicitly prove that microfinance influence empowerment. Consequently, loan cycles-with one loan granted per loan cycle - were used as independent variable in order to measure the effect of microfinance on empowerment. The approach bases upon the assumption that the effect of microfinance on empowerment does not emerge until the business that was financed through the microloan creates a stable financial return. New borrowers being in the first loan cycle will not experience an effect on empowerment at this stage because the time for the loan to cause this effect is too short.

\section{Methodology and data description}

In the light of previous studies and theoretical frame work, we will select the dependent and independent variables to design the empirical model of this study. Besides the variables microfinance as one of the independent variables, we include other factors as control variables. Details are given below:

\subsection{Models for Women's household decision making empowerment}

Model $\mathrm{Y}_{1}$ include microfinance involvement dummy variable and loan size.

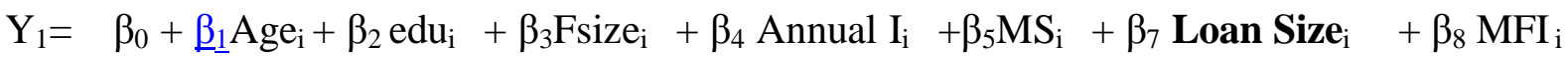
$+\beta_{9}(\mathrm{LS} * \mathrm{edu})_{\mathrm{i}}+\mathrm{ei}$

As women's empowerment is qualitative variables, we used the multinomial Logit and multinomial Probit model to measure the impact of microfinance on women's empowerment. The STATA was used for analysis. In the light of the model, to analyze the impact of microfinance on woman's empowerment, we selected the women's household decision making empowerment as dependent variable while age, education, family size, annual income, marital status and involvement with microfinance, loan size are taken as independent variables.Y1 is measured into three categories " 0, , " 1 " and 2 , age, education (edu),family size(Fsize), annual income (Annual I) was measured in numeric values(numbers) while marital status(MS) and involvement in microfinance (Mfi) were measured in dummy variables. 0 shows to unmarried women and to women who are not involve in microfinance and 1 shows to married women women who are involvement in microfinance. 


\section{Data Collection Strategies}

The cross sectional data for this study was collected by using a questionnaire. Data on women empowerment was collected from two types of women: first the women who were not involved in microfinance, and second the women who were clients of Khushhali Bank and National Rural Support Programme. Most of the questions that were used in the questionnaire were from Pitt, Khandker and Cartwright (2006) study.Hence, out of the total population of 5,439 microfinance women clients, we took744 client women as sample from Bahawalpur, Punjab Pakistan. A stratified random sample of 744 household were drawn from the population, approximately 372 questionnaires were filled through female clients of Khushhali Bank and National Rural Support Programme while 372 questionnaires were filled through those women who are not involved in microfinance.

\section{Empirical results of Multinomial Probit model estimation}

In sometime ability relative to no ability condition here is the variable age that has insignificant and positive relation with the women empowerment in decision making. In full ability compare to no ability, age is significant at 5 percent and positively related with decision making. Age means maturity and maturity leads to empowerment. As a little girl grown up, she is moving to maturity, and this maturity leads her to strong in her decision. The age coefficient has positive and significant relation with women empowerment in decision making. Education in the interaction term is not significant, most of the women in our sample were illiterate. In sometimes ability compare to no ability, education is insignificant but positively related while in full ability compare to no ability The variable education has positive and significant at 1 percent relation with women empowerment in decision making. Educated women's are more powerful in decision making than that of uneducated women. The educated women are being considered an icon of beauty in her decision making.

Table 1:Results of Multinomial Logit Model estimation

\begin{tabular}{|c|c|c|c|c|}
\hline Variables & \multicolumn{2}{|c|}{ Som exim es bility rdive to No ability } & \multicolumn{2}{|c|}{ Full ability relive to no ability } \\
\hline & Coef. & Std. Err. & Coof & Std. Err. \\
\hline Age & .0079299 & .0055445 & $.0190799 * *$ & .0097052 \\
\hline Edecation & .1057726 & .0521735 & $2641704^{* * *}$ & .090162 \\
\hline Family aize & $.0551605^{*}$ & .0393738 & $.1110383+\infty *$ & .0423921 \\
\hline Income & $9.5405^{* * *}$ & 3.6996 & $.0000125 * *$ & 3.850 .05 \\
\hline Marial sates & -2770243 & 3323635 & 0.3252025 & 3418447 \\
\hline Losesize & $.0000525 * 0$. & .0000007 & $.0002263^{* * *}$ & .0000202 \\
\hline $\begin{array}{l}\text { MGerofiesece } \\
\text { invol vem at }\end{array}$ & $.755958 * \cdots$ & 2657025 & $3.350583 \cdots$ & .272445 \\
\hline $\mathrm{E} d \mathrm{du} * \mathrm{LS}$ & $-1.900-05$ & $9.310-05$ & -5.78 & 8.765 \\
\hline$-\infty \mathrm{nx}$ & -7683435 & 5191525 & -3.052576 & 5745471 \\
\hline & elibood =-608. 85034 & $\operatorname{LR} \operatorname{di2}(14)=365.1$ & Prob>cki2 0.0000 & \\
\hline
\end{tabular}

Note: 1 (sometime ability) (base outcome) Sometimes ability is the a base outcomes * $* *, * *$ and $*$ indicate that variables are significant at $1 \%, 5 \%$ and $10 \%$ level of significance 
respectively.

In sometimes ability and full ability compare to no ability education is significant $t 5$ percent and in full ability relative to no ability family size is significant at 1 percent and has a positive relationship with household decision making. This is because in a large family they are to take care of family members about health, meal, basic need, etc. In lager family if a woman is talking about household decision if one person will not value to her words and decision, the other family member can support her decision, when all family member discuss the matter to make a decision, women will also be one member in discussion if her decision or suggestion is wise there will be maximum chances to choose wise decision when many people are discussing and trying to make the best decision. So, when any respondent has large family size they take care of one another, and they can consider her decision that women make. According the previous studies. Family size of women will be calculated through the number of individuals of household who live under the same house and eat together.(Hashemiet al. 1996, Banu et al. (2000), Becchetti 2009, and Bandyopadhyayet al. 2011, use family size to check the impact of micro finance on women's empowerment. Tuseef (2011) family size is positively correlated and significant with women empowerment this is because in a large family they are to take care of the family members about food servicing, cloth servicing, and health, etc. When female gets any problem, she is supported morally and financially by her family member. The variable income variable has positive but significant at 1 percent in both sometimes ability and full ability compare to no ability, As income increase the women empowerment in decision making will increase. Women's income has a positive relation with her decision making ability because working women have a strong influence of her personality in the family and can be dominant in the family. That is why the trend of the society in Pakistan going change and every one want to work women as his life partner just because not of the reason that she will brought up her kids well, but it is the need of the every family to increase their family income. Better life is only possible if both members are working hand (wife and husband). If the women is earning her decision can be considered, in the general observation in Pakistani society working women who earn money even in her family she has power full status compare than a family member who is not earning. Parents also try to give them good education that will be the result in good earning they suppose if their daughter will earn she can find good suitor/ husband. So, when women earn than they can part of household decision. According to the previous studies, Parveen, 2007, Noreen 2009 and Tuseef 2011, use annual income to check the impact of micro finance on woman's empowerment. Mayoux (2005) said that, spiral process of women empowerment including three paradigms (financial self-sustainability, poverty alleviation and feminist empowerment). In the case of financial self-sustainability paradigm, increasing income create women control over their income that increases wage and employment for women. In the case of poverty alleviation paradigm, income enhances women's decision about consumption that increase welfare of women and improved welfare for women enable women to bring about wider changes in gender inequality. Lastly, in case of feminist empowerment paradigm, income increase women's status and increasing women's status improves the ability to negotiate change in gender relation. Increasing wage and employment opportunity and ability to negotiate change in gender relation increases mobility and 


\section{Macrothink}

knowledge of social, legal and political issues. In both sometime ability and full ability compare to no ability, marital status is insignificant but positively lated in the full ability. When we talk only about change marital status of women, the case is different. If a woman are married her decision cannot be considered by her husband according the results, in family size her decision are considered because in family size there are other people with different age, education, earning status, minds and financial status to support her decision if her decision is wise, in a big group /family size chances of acceptance of wise decision can be more than a single person. This is might be in Pakistan women get married in early age as in our sample 82 percent women were married while 18 percent women were unmarried. In our data, 54 percent women are young it is supposed that age as age increase experience increases that hick the household decision making. Nessa.T (2011) also found the same result about impact of marital status on women household decision making; Asim (2009) found the marital status insignificant in household decision making in his studies at Pakistan. In sometimes ability and full ability relative to no ability, the variable loan size has positive and significant relation with women empowerment. it is supposed if a women borrow the earn and their decisions are considered. So we would reject the null hypothesis. Result of our study is similar with the results of Parveen, 2007, Hashemiet al. 1996, and Banuet al. (2000)found that loan size has a positive impact on women's empowerment. Bandyopadhyayet al. (2011) use the loan size to see the impact of microfinance on woman's empowerment because if a female has a larger loan size she can start a good business and can earn more. Amount of loan positively affects the empowerment of woman when the loan is utilized by woman. Goetz and Sengupta (1996) argue that the amount of loan can influence the effect of microfinance on women's empowerment. Results also show the women who are involved in microfinance they are more empowered in household decision making.

\subsection{Impact of change in the explanatory variable on women household decision making empowerment}

According Richard Williams (2012) we get marginal effects of the component terms. The value of the interaction term cannot change independently of the values of the component terms, so we cannot estimate a separate effect for the interaction." The estimated coefficients in the multinomial logit model are of limited use because they cannot be used to infer the direction of the marginal effect of each explanatory variable, the marginal effect of a given variable on the probability of choosing any ability of household decision making (no ability, sometimes ability and full ability) is a function of all of the estimated. 


\section{Macrothink

Table 2: Results of Marginal Effect

\begin{tabular}{|c|c|c|c|}
\hline Variable & No ability & Som time ability & Fall ability \\
\hline Ago & $\begin{array}{c}.0007079 \\
(0.252)\end{array}$ & $\begin{array}{c}.0002469 \\
(0.857)\end{array}$ & $\begin{array}{c}-.0009549 \\
0.609)\end{array}$ \\
\hline Fdeation & $\begin{array}{c}-0038776 \\
(0.202)\end{array}$ & $\begin{array}{c}-0090142 \\
(0.210)\end{array}$ & $\begin{array}{c}.0115915^{*} \\
0.055)\end{array}$ \\
\hline Family \$ & $\begin{array}{c}-0058125 \\
(0.051)\end{array}$ & $\begin{array}{c}-0073352 \\
(0.331)\end{array}$ & $\begin{array}{c}.0131457 \\
0.105)\end{array}$ \\
\hline Income & $\begin{array}{l}1.035 \\
(0.000)\end{array}$ & $\begin{array}{c}-1.03 .05^{*} \\
(0.057)\end{array}$ & $\begin{array}{c}2.055^{* 0 *} \\
0.002)\end{array}$ \\
\hline Marital S & $\begin{array}{c}505775 * 0 . \\
(0.004)\end{array}$ & $\begin{array}{c}-0004058 \\
(0.997)\end{array}$ & $\begin{array}{c}-5053592 * . . \\
0.001)\end{array}$ \\
\hline Loses Sire & $\begin{array}{c}2.12 \cdots \\
(0.000)\end{array}$ & $\begin{array}{l}9.655^{* *} \\
(0.013)\end{array}$ & $\begin{array}{c}.0000115^{* 0 *} \\
0.005)\end{array}$ \\
\hline $\mathrm{mfi}^{*}$ & $\begin{array}{c}3454503 * 0 . \\
(0.000)\end{array}$ & $\begin{array}{c}-2554583^{* 0 *} \\
(0.000)\end{array}$ & $\begin{array}{c}.60190^{* 0 *} \\
0.000)\end{array}$ \\
\hline
\end{tabular}

Note. The figures in parenthesis are p-values; $* * *, * *$ and ${ }^{*}$ denote that the corresponding coefficient is significant at the $1 \%, 5 \%$ and $10 \%$ level, respectively. Mfi refers to the microfinance involvement. No ability is the base outcome

Hence, we proceed by calculating the marginal effect of each explanatory variable on the probability of choosing each type ability of household decision making. As documented in Table, we find the following results. First, the marginal effect of respondent's age on the probability of choosing ability of household decision making is insignificant for all, (no ability, sometimes ability and full ability) but have a positive relation with all choices (no ability, sometimes ability and full ability Second, the marginal effect of respondents' education on the probability of choosing ability of decision making is significant for the full ability only. In particular, if the education of the respondent increases by one year, the probability of choosing full ability is expected to rise by .0118918 . These results indicate that the full ability of decision making appears to cater to educated people while no ability and some time ability seem to be indifferent towards the education of the respondent. Third, the marginal effect of family size on the probability of choosing no ability is significant. In particular, if the number of family size increases by one person from its mean value of persons, the probability of choosing full ability is expected to decline by -.0058125 . These results suggest that sometimes ability and full time ability appear to cater to relatively small family size while full ability to relatively large family size. Fourth, the marginal effect of annual income of the respondent on the probability of choosing full ability is significant. In particular, if the number of annual income of respondent increases by PKR, 1000 from its mean value of income, the probability of choosing full ability is expected to rise by 2.066 , the probability of choosing sometime ability and no ability is significant, but negatively related 


\section{Macrothink}

with household decision making. No ability is expected to fall by -1.036 and sometimes ability will fall by.103. These results suggest that no ability and sometimes the ability appear to cater to relatively low income while full ability to relatively high income.

Fifth, the marginal effect of marital status of the respondent on the probability of choosing full ability is significant. In particular, if the respondent gets married, the probability of choosing full ability is expected to rise by .242 , the probability of choosing sometime ability is insignificant but positively related with household decision making. No ability is expected to fall by-.188. These results suggest that no ability appear to cater to relatively unmarried while full ability to relatively married. Sixth, the marginal effect of marital status of the respondent on the probability of choosing no ability is significant. In particular, if the respondent gets married, the probability of choosing no ability is expected to rise by .506 , the probability of choosing $\mathrm{s}$ full ability is significant, but negatively related with household decision making. Full ability is expected to fall by-.506 and sometimes the ability is expected to fall by -.000405 . These results suggest that the full ability and sometimes the ability appear to cater to relatively unmarried while full ability to relatively married. This is because in our sample size only3.2 percent women were unmarried.

Seventh, the marginal effect of respondents' loan size on the probability of choosing ability of decision making is significant for the full ability only. In particular, if the loan size of a respondent increases by PKR: 1000, the probability of choosing full ability is expected to rise by .0000118 . These results indicate that the full ability of decision making appears to cater to educated people while no ability and some time ability seem to be indifferent towards the education of the respondent. Finally, the marginal effect of involvement in microfinance on the probability of choosing a full ability is significant. In particular, if women involve in microfinance increases by RM1,000 from its mean value of RM4,068, the probability of choosing no ability and sometimes the ability is expected to fall by -.3464503 and -.2554583 respectively, while the probability of choosing full ability is significant and expected to rise by .60190 .

\subsection{Robustness check}

In the robustness check, all the results are consistent with multinomial probit mode estimation. 
Table 3: Results of Multinomial Probit model estimation.

Coef.

Age

Education

Family size

Income

Marital status

Loan Size

Edu* LS

Microfinance

involvement

cons
Std. Err.

Coef.

$.0142883 * *$

$.1974863 * * *$

.0575091

.075613

.059333

$.0850334 * * *$

.0313954

.0526042

.030025

$2.78 \mathrm{e}-06$

$9.67 \mathrm{e}-06 \quad * * *$

$2.89 \mathrm{e}-06$

7.41e-06 ***

$-.183284$

$.0000429 * * *$

.2560133

.2584518

.2516459

.000014

$.0001713 * * *$.

0000138

$-1.73 \mathrm{e}-06$

$5.98 \mathrm{e}-06$

$-5.35 \mathrm{e}-06$

5.73e-06

$.5286563 * * *$

.187349

$2.556005 * * *$

.188575

$-.628059$

.4007499

$-2.367903$

.4225016

Note: 1 (sometime ability) (base outcome) Sometimes ability is the a base outcomes.***,**

\section{Conclusion}

The purpose of this paper is to evaluate the impact of the microfinance involvement of women's household decision making. The cross sectional data for this study is collected by using questionnaires. Using random sampling, 744 households are selected from female clients of Khushhali Bank and National Rural Support Program in Bahawalpur Division, Pakistan. We used the multinomial Logit and multinomial probit model. The results show the woman's borrowers are more empower than women no borrowers. Age, education, family size is significant and have positive relationship with household decision making. As income increase the women empowerment in decision making will increase. Women's income has a positive relation with her decision making ability because working women have a strong influence of her personality in the family and can be dominant in the family. Marital 
status doesn't has impact on the decision making. The interaction term between education and loan size don't has impact on women's household decision. This is might be because most of the women in sample were illiterate. The coefficient of the loan size increases woman's household making empowerment. This paper is intended to be a valuable contribution in term of socio- economic and political arena.

\section{References}

Ai C, Norton EC (2003) Interaction Term in Logit and Probit Models. Economic Letters 80:123-129. The Stata Journal, 2004, 4(2):103-116.

Ali, I., \&Hatta, Z. A. (2012). Women's empowerment or disempowerment through microfinance: Evidence from Bangladesh. Asian Social Work and Policy Review, 6(2), $111-121$.

Amin, R.; Becker, S.; and Bayes, A. (1998).NGO-Promoted Micro credit Programs and Women's Empowerment in Rural Bangladesh: Quantitative and Qualitative Evidence, The Journal of Developing Areas, Vol. 32, No. 2, pp. 221-36.

Asim, S. A. (2008). Evaluating the Impact of Microcredit on Women's Empowerment in Pakistan, CREB Working Paper No.2- 9, Social Science Research Network.

Banu, D., Farashuddin, F., Hossain A., \&Akter, S. (2000), Empowering women in rural Bangladesh: Impact of BRAC's program.

BartualSanfeliu, C., Cervello’ Royo, R., \&Moya Clemente, I. (2013).Measuring performance of social and non-profit Microfinance Institutions (MFIs): An application of multicriterion methodology. Mathematical and Computer Modelling, 57(7-8), 1671-1678. http://

Becerril, J., \&Abdulai, A. (2010). The impact of improved maize varieties on poverty in Mexico: A propensity score-matching approach. World Development, 38(7), 1024-1035,

Bhatt, N., \& Tang, S.-Y. (2001). Delivering microfinance in developing countries: Controversies and policy perspectives. Policy Studies Journal, 29(2), 319-333. http://dx.doi.org/10.1111/j.1541- 0072.2001.tb02095.x.

C1DA (2002). C1DA and Microfinance: A Poverty Reduction Approach Canadian International Development Agency, Policy Branch.

Caliendo, M., \&Kopeinig, S. (2008). Some practical guidance for the implementation of propensity score matching. Journal of Economic Surveys, 22(1), 31-72.

Carolyn, Hannan, (2003). Transforming Empowerment and Gender Mainstreaming, International Symposium on a new Vision for Gender Policy: Equality, Development and Peace. New York April,2003.

Charmes, J., \&Wieringa, S. (2003). Measuring women's empowerment: An assessment of the gender-related development index and the gender empowerment measure. Journal of Human Development, 4(3), 419-435. http://dx.doi.org/10.1080/1464988032000125773. 


\section{Macrothink}

Journal of Entrepreneurship and Business Innovation ISSN 2332-8851 2014, Vol. 1, No. 1

Chaudary and Nosheen (2009). The Determinants of Women Empowerment in Southern Punjab, Pakistan: An Empirical Analysis, European Journal of Social Sciences, Vol 10-2.pp.101-117

Cheston, S. and Lisa, K. (2002). Empowering women Through Microfinance, Washington: UN IFEM for Micro-credit Summit, 2002.

Chowdhury, S. S., \&Chowdhury, S. A. (2011). Microfinance and women empowerment: A panel data analysis using evidence from rural Bangladesh. International Journal of Economics \& Finance, 3(5), 86-96. http://dx.doi.org/10.5539/ijef.v3n5p86.

Conger, J. A., \&Kanungo, R. N. (1988). The empowerment process: Integrating theory and practice. The Academy of Management Review, 13(3), 471-482.

Cull, R., Demirguec_-Kunt, A., \&Morduch, J. (2007). Financial performance and outreach: a global analysis of leading microbanks. The Economic Journal, 117(517), F107-F133.

De Gobbi, M.S. (2005). Nepal and Pakistan, Microfinance and Micro Development Their Contribution to the Economic Empowerment of Women, SEED Working Paper No. 69 ILO Geneva.

Dehejia, R. H., \&Wahba, S. (2002). Propensity score-matching methods for nonexperimental causal studies. Review of Economics and Statistics, 84(1), 151-161.

Diamond, A., \&Sekhon, J. S. (2012). Genetic matching for estimating causal effects: A general multivariate matching method for achieving balance in observational studies. Review of Economics and Statistics,

Duvendack, M., \& Palmer-Jones, R. (2012). High noon for microfinance impact evaluations: Re-investigating the evidence from Bangladesh. Journal of Development Studies, 1-17,

Farooq, O. M. (2009). The challenge of poverty and mapping out solutions: Requisite paradigm shift from a problem-solving and Islamic perspective, Journal of Islamic Economics, Banking and Finance, Volume-5 Number-2, pp.45-76

Fetterman, D. M. (1994).Empowerment evaluation. Evaluation Practice 15(1), 1-15.

Godquin, M. (2004). Microfinance repayment performance in Bangladesh: How to improve the allocation of loans by MFIs. World Development,

Goetz, Anne Marie; and Gupta, RinaSen (1996). Who Takes the Credit? Gender, Power, and Control Over Loan Use in Rural Credit Programs in Bangladesh, World Development, Vol. 24, No. 1, pp. 45-63.

Government of Pakistan, (2004-05) Economic Survey of Pakistan, Islamabad, Ministry of Pakistan.

Haile, H. B., Bock, B., \&Folmer, H. (2012). Microfinance and female empowerment: Do institutions matter?. Women's Studies

Handy, F. and Kassam, M. (2004), Women's empowerment in rural India. Paper presented 
at the ISTR conference, University of Toronto, Canada, july,2004

Hashemi, S. M., Schuler, S. R., \& Riley, A. (1996). Rural credit programs and women's empowerment in Bangladesh, World Development, Vol. 24, No. 4, pp. 635-653.

Hausmann, R., Tyson, L. D. A., \&Zahidi, S. (2008). The global gender gap report 2008.

Hermes, N., \&Lensink, R. (2011). Microfinance: Its impact, outreach, and sustainability. World Development, 39(6), 875-881. http://dx.doi.org/ 10.1016/j.worlddev.2009.10.021.

Hishigsuren, G. (2007). Evaluating mission drift in microfinance. Evaluation Review, 31(3), 203-260.

Holvoet, N. (2005). The Impact of Microfinance on Decision-Making Agency: Evidence from South India, Development and Change,Blackwell Publishing, Institute of Social Studies vol. 36 (1),pp. 75-102

Hope, R. A. (2007). Evaluating social impacts of watershed development in India.World Development, 35(8), 1436-1449, http://dx.doi.org/ 10.1016/j.worlddev.2007.04.006.

Hoque, M., \&Itohara, Y. (2009). Women empowerment through participation in microcredit program: A Case study from Bangladesh. Journal of Social Science, Vol 5-3, pp 244-250

Human Development Report (1995), United Nations Development Programme, Oxford University Press, New York.

Hunt, J. and Kasynalhan,N.(2002). 'Reflections on microfinance and women's empowerment, Development Bulletin, No. 57, pp. 71-75

Hunt, J., \&Kasynathan, N. (2001). Pathways to empowerment?Reflections on microfinance and transformation in gender relations in South Asia. Gender \& Development, 9(1), 42-52.

Iacus, S. M., King, G., \&Porro, G. (2012). Causal inference without balance checking: Coarsened exact matching. Political Analysis, 20(1), 1-24.

ILO (1998).Women in Informal Sector and Their Access to Microfinance, Inter-Parliamentary Union Annual Conference, Windhoek, Namibia, 2-11 April 1998 Indian National Policy for Empowerment of Women. (2001).

Jalan, J., \&Ravallion, M. (2003).Estimating the benefit incidence of an antipoverty program by propensity-score matching. Journal of Business \& Economic Statistics, 21(1), 19-30.

Jejeebhoy, S. J., \&Sathar, Z. A. (2001). Women's autonomy in India and Pakistan: The influence of religion and region. Population and Development Review, 27(4), 687-712.

Journal of Business Management, 6(12), 4514-4521. http://dx.doi.org/ 10.5897/AJBM11.2407.

Kabeer and Naila (2001). Reflections on the Measurement of Women's Empowerment: In Discussing Women's Empowerment-Theory and Practice, Swedish International Development Agency, Stockholm, Sida Studies No. 3. NovumGrafiska AB: S, pp. 17-59 
Kabeer, N. (2001). Conflicts over credit: Re-evaluating the empowerment potential of loans to women in rural Bangladesh. World Development, 29(1), 63-84,

Kabeer, N. (2005). Gender equality and women's empowerment: A critical analysis of the third millennium development goal 1. Gender \& Development, 13(1), 13-24.

Kashf Foundation (2011). Annual Report 2009-2010. Lahore: Kashf Foundation.

Kashf Foundation. (2010). Economic gains through the provision of financial services to women in Pakistan (pp. 4). Lahore, Pakistan: Kashf Foundation.

Katchova, A. L. (2010). Agricultural contracts and alternative marketing options: A matching analysis. Journal of Agricultural \& Applied Economics, 42(2), 261-276.

Kavitha,N. (2007). Role of Women IN Microfinance, SSM College of Engineering, Research report, Tamil Nadu, India.

Khan, M. A., Alam, M. F., \& Islam, K. J. (2012). The impact of comanagement on household income and expenditure: An empirical

Khandker, and Shahidur R. (1998). Fighting poverty with microcredit: Experience in Bangladesh. Report, Oxford University Press, October, 1998

Khandker, S. R. (2005). Microfinance and poverty: Evidence using panel data from Bangladesh. The World Bank Economic Review, 19(2), 263-286.

Malhotra, A. Schuler S.R. and Boender, Carol, (2002): Measuring Women's Empowerment as a Variable in International Development, Background Paper for World Bank Workshop on Poverty and Gender: New Perspectives.

Malhotra, A., \& Schuler, S. R. (2005).Women's empowerment as a variable in international development. In D. Narayan (Ed.), Measuring empowerment: Cross-disciplinary perspectives (pp. 71-88). Washington, DC: The Wirkd Bank.

Malhotra, A., Schuler, S. R., \&Boender, C.(2002). Measuring women's empowerment as a variable in international development, background paper prepared for the World Bank workshop on poverty and gender: New perspectives, June 28, 2002.

Mason, K.O. and Herbert L. Smith, (2003). Women's Empowerment and Social Context: Results from Five Asian Countries, The World Bank Washington D.C Rockefeller Foundation's Bellagio Study and Conference Center, 2 January 2003

Mayoux, L. (1997). The magic ingredient?Microfinace and women empowerment: Towards a Framework for Participatory Planning, Background Discussion Paper, ActionAid UK Washington, February 1997

Mersland, R., \&Strøm, R. Ø. (2010). Microfinance mission drift?. World Development, 38(1), 28-36. http://dx.doi.org/10.1016/j.worlddev. 2009.05.006.

Michael Pennock.(2006).The Gross National Happiness Abridged Survey, Population Health Epidemiologist, Vancouver Island HealthAuthority, Victoria, BC. Canada 
Microfinance gateway, http://www.microflnancegateway.org/sec/fa

Ministry of Finance of the Government of Pakistan. (2013). Pakistan Economic Survey 2012-2013 Retrieved October 11, 2013, from

Montgomery, H., \& Weiss, J. (2011). Can commercially-oriented microfinance help meet the millennium development goals? Evidence from Pakistan. World Development, 39(1), 87-109. http://dx.doi.org/ 10.1016/j.worlddev.2010.09.001.

Morduch, J. (1999). The role of subsidies in microfinance: Evidence from the Grameen Bank. Journal of Development Economics, 60(1), 229-248. http://dx.doi.org/10.1016/s0304-3878(99)00042-5.

Morvant-Roux, S., Gue'rin, I., Roesch, M., \&Moisseron, J.-Y. (2014). Adding value to randomization with qualitative analysis: The case of microcredit in rural morocco. World Development, 56, 302-312, http:// dx.doi.org/10.1016/j.worlddev.2013.03.002.

Mosedale, S. (2005). Assessing women's empowerment: Towards a conceptual framework. Journal of International Development, 17(2), 243-257. http://dx.doi.org/10.1002/jid.1212.

Muhammad, S. D., Shaheen, G., Naqvi, S. I. H., \&Zehra, S. (2012). Women empowerment and microfinance: A case study of Pakistan. African Journal of Business Management, 6(22), $6497-$

Niaz, U. (2003). Violence against women in South Asian countries.Archives of Women's Mental Health, 6(3), 173-184.http://dx.doi.org/ 10.1007/s00737-003-0171-9.

Niethammer, C., Saeed, T., Mohamed, S. S., \&Charafi, Y. (2007).Women entrepreneurs and access to finance in Pakistan. Women's Policy Journal of Harvard, 4, 1-12, Summer 2007.

Noponen, H. (2003). 12. The internal learning system - A tool for tracking and enhancing empowerment outcomes and wider social impacts of microfinance. IDS Bulletin, 34(4), 121-132.

M. (1999).Bringing development back, into microfinance. Journal of Microfinance, 1(1), $8-19$.

Pakistan Microfinance Network (2003) .Performance indicators Report, Pakistan Microfinance Network Secretariat, Islamabad.

Pakistan. (2009). Health of women in Pakistan Annual Report (pp. 8). Karachi, Pakistan: Society of Obstetricians \&Gynaecologists of Pakistan.

Parveen, S. (2007). Gender awareness of rural women in Bangladesh.

Parveen, S. and Ingrid- Ute Leohauser, (2004). Empowerment of rural women In Bangladesh: A Household Level Analysis, Conference On Rural Poverty Reduction Through Research And Transformation, DcutscherTropentag- Berlin- Germany.

Rahman, M. H., \&Naoroze, K. (2007). Women empowerment through participation in aquaculture: Experience of a large-scale technology demonstration project in Bangladesh, 
Journal of Social Science, volume,2, pp. 164-171.

Rahman, M.H. and KaziNaoroze (2007). Women Empowerment Through Participation In Aquaculture: Experience Of A Large Scale Technology Demonstration Project In Bagladesh, Journal Of Social Science 3(4) pp. 64-171

Rowlands, Jo. (1995). Questioning Empowerment. Working with women in Honduras. London: Oxfam United Kingdom

Sathar, Z. A., \&Kazi, S. (2000). Women's autonomy in the context of rural Pakistan. The Pakistan Development Review, 39(2), 89-110.

Schuler, S. R., \&Rottach, E. (2010).Women's empowerment across generations in Bangladesh. The Journal of Development Studies, 46(3), 379-396. Society of Obstetricians \&Gynaecologists

Skarlatos, k. (2004).Microfinance and Women.s Economic Empowerment. Bridging the Gap, Redesigning the Future..Working Paper No 1, Wisconsin Coordinating Council in Nicaragua.

Sukontamam, P. (2007). Micro-credit, fertility decisions, and women's empowerment in Bangladesh, working paper No 94, University of Adelaide.

Swain, R. B., \&Wallentin, F. Y. (2007). Does microfmance empower women? Evidence from Self Help Groups in India, working paper No.24,department of economics, Uppsala University, August 2007

Swain, R.B. (2007a). Can Microfinance Empower Women? Self Help Group in India, Department of Economics, UPPSALA University, ADAN.37

Swain, R.B. (2007b). Does Microfinance Empower Women? Evidence from Self Help Group in India, Working Paper No. 24, UPPSALA University, Department Of Economics.

The Millennium Development Goals Report. (2006).

Todaro, M.P. (2003). Economic Development. Eighth Edition, Addison Wesley Longman, Singapore.

Umashankar, D. (2006). Women's empowerment: Effect of participation in self-help groups.

UNDP Report. (2008).

UNDP. (1995). Human Development Report, New York: Oxford University Press.

wikipedia report. (2008).

World Health Organization (WHO).(1995). Presentation to the Fourth World.Conference on Women. Beijing, China.

ZubiaMumtazand Sarah Salway (2005), "I never go anywhere': extricating the links between women's mobility and uptake of reproductive health services in Pakistan", Social Science \& Medicine, Volume 60, Issue 8, April 2005, Pages 1751-1765. 
